\title{
REFERENCES
}

Britannica Book of the Year, Encyclopaedia Britannica, Chicago, 1990.

Encyclopaedia Britannica, Chicago, 1985, 32 volumes.

Spits, F.C., 'Klassedienstplicht in de negentiende eeuw,' in: Driekwart eeuw historisch leven in Den Haag, 's-Gravenhage, 1975.

Tinbergen, J., 'The Velocity of Integration,' De Economist, 139 (1991), pp. 1-11.

\section{DIFFERENT TYPES OF INTEGRATION, AN ANSWER TO SNAPPER}

Snapper's article constitutes a considerable enrichment of the theory of integration. The difference between voluntary co-operation of sovereign entities and unification imposed by war is essential. What we share is the search for the quantification of integration, which in most cases makes scientific research more useful. The concept of duration of development (Tinbergen 1992), ${ }^{1}$ another exampe of quantification, illustrates that statement. Snapper's qualification shows the use of this concept. My first attempt at a theory of integration, the impact of language difference, will, I hope, be followed by the introduction of other explanatory factors. Snapper's contribution is such an elaboration. A better theory of integration may help us to find means to accelerate integration, achieve world integration sooner than we are envisaging at present, and thus avoid the possible disasters mankind is now facing: war, pollution, or exhaustion of natural resources.

Jan Tinbergen

1 J. Tinbergen, Diverging Incomes and the Duration of Development, 1992, forthcoming. 